\title{
Weapons of the Weak: The Violent Consequences of Biased Technological Change
}

\author{
Aditya Dasgupta ${ }^{1}$
}

Word Count: 8167

\begin{abstract}
:
Technological change is typically biased, producing wealth that is distributed unequally across groups in society. When the relative losers of technological change lack the political power needed to pursue redistribution through the political system, they may turn to informal tactics of protest and redistribution, include violence. The argument is applied to the green revolution in India. The spread of a new crop technology, high-yielding variety (HYV) crops, improved agricultural productivity, but also generated rising inequality between landowners and the rural poor. Drawing on a panel dataset linking district-level estimates of HYV crop adoption to digitized crime records, this paper provides evidence that the spread of the new crop technology contributed to an epidemic of dacoity (banditry), an economic crime with elements of social protest against inequality. However, the spread of the new crop technology did not benefit leftwing parties electorally, suggesting that violence was not a precursor to but substitute for redistribution at the ballot box.
\end{abstract}

${ }^{1}$ Assistant Professor of Political Science, University of California, Merced. Email: adasgupta3@ucmerced.edu. Mail: 5200 North Lake Road, Merced, CA 95343. Thanks to seminar participants at the Annual Conference on South Asia at the University of Wisconsin, Madison and the Center for the Advanced Study of India at the University Pennsylvania for their valuable feedback. 


\section{Introduction}

Technological change is a fundamental driver of wealth and prosperity. However, technological change is also typically biased, in the sense that new technologies often increase the productivity of some factors of productions (such as land, capital, skilled labor, etc.) more than others. As a result, the wealth that is generated by technological change is often distributed unequally across groups in society, producing relative winners and losers and, quite often, periods of rapidly rising economic inequality.

Important theories suggest that biased technological change ought to incentivize the relative losers of technological change ought to seek redistribution or compensation through the political system. For instance, Karl Marx famously argued that the inequality and class conflict generated by technological change during the industrial revolution would result in a working-class political revolution, as workers organized first through trade unions and then through political parties. Contemporary models in political economy make comparable predictions. For instance, the model of Meltzer and Richard (1981) predicts that equilibrium voter support for redistribution increases with the level of inequality in society and the "compensation hypothesis" predicts that governments ought to compensate relative economic losers in order to maintain continuing political support (Katzenstein 1985; Rodrik 1998).

However, it is not clear that the historical record actually supports these predictions. For instance, until the late nineteenth century, the gains from technological change during the industrial revolution were concentrated among capital while wages stagnated (see e.g. Allen 
2009), yet this produced little large-scale redistribution, let alone a communist revolution. More recently, in industrialized countries, skill-biased technological change since the 1980s has contributed to rapid growth in earnings inequality between blue-collar and white-collar workers (see e.g. Autor, Levy, and Murnane 2003), yet there has been little observable increase in redistribution or leftward drift in the locus of political competition.

This paper develops a modified hypothesis. For a variety of reasons - for instance, a lack of numbers or resources, or an oligarchic and unresponsive party system - the relative losers of technological change may lack the political power needed to pursue redistribution or compensation through the formal political system. In these contexts, they may resort to informal or everyday forms of protest and redistribution, including crime and violence. Far from senseless, this violence is better seen as a form of contentious politics serving two potential strategic purposes: first, expression of protest against rising inequality; and, second, informal redistribution of the surplus generated by technological change. However, it is important to keep in mind that these tactics represent not the incipient stages of large-scale collective action at the ballot box but (sometimes, quite literal) "weapons of the weak" - to draw on the terminology of Scott (2008) - because they are typically adopted by groups that lack the political power to advance their aims through open conflict in the formal political system. If correct, the argument can help to make sense of why we observe so little redistribution of the surplus generated by technological revolutions as well as the upsurge of crime, violence, and contention that often accompanies these periods. 
The argument is applied to a major twentieth-century technological revolution in agriculture: the green revolution in India. The introduction and spread of a new crop technology, high-yielding variety (HYV) crops, between the 1960s and 1980s produced large improvements in agricultural productivity, but also rising rural inequality, because the new crop technology was characterized by economies of scale that made it more profitable to cultivate by larger-scale farmers. This paper empirically investigates the link between the spread of the new crop technology and rising rural violence by assembling a new historical panel dataset linking district-level estimates of the share of agricultural land planted with HYV crops to newly digitized archival data on districtlevel crime records.

Panel fixed-effects regressions show that districts experiencing increases in the share of agricultural land planted with HYV crops also experienced a large increase in the occurrence of dacoity, a form of crime with elements of social protest against inequality. Placebo tests utilizing every other form of recorded crime, including other forms of economic crime, reveal no connection to HYV crop adoption, suggesting that the epidemic of dacoity in districts where the new crop technology was spreading was driven not just by opportunistic plundering but a selective form of violence representing protest against rising rural inequality as well as smallscale redistribution from rich to poor. Additional analyses reveal that increases in HYV crop adoption did not strengthen the electoral performance of left-wing parties, suggesting that the epidemic of banditry was not a precursor to but a substitute for large-scale collective action at the ballot box, which would have been prohibitively difficult in a hierarchical rural context where local party organization was dominated by rural elites, and where linkages to the rural poor typically took the form of patron-client ties. 
The findings contribute to debates about the political economy of inequality and redistribution. Though canonical theories in political economy predict that political support for redistribution will increase with the level of inequality in society, they do not consider what happens when those excluded from the gains of biased technological change lack the political power needed to pursue redistribution or compensation through the formal political system. The findings suggest that one possible response is a resort to informal forms of protest and redistribution, including crime and violence. In the context of rural India, available "repertoires of contention" meant that this resulted in an epidemic of rural banditry, though these tactics would likely differ in other historical and social contexts.

The findings also relate to a growing empirical literature on the political consequences of technological change, especially in agriculture. Dasgupta (2018) finds that the winners of technological change during India's green revolution, landowning farmers, mobilized behind new agrarian parties representing their interests. This paper provides evidence that the relative losers of technological change, the rural poor, resorted instead to violence because their demands did not find expression in the party system. Scott (2008) and Goody (1980) provide ethnographic evidence of social unrest among the rural poor during the green revolution in Malaysia and Ghana, respectively. Voth and Caprettini (2019) provide evidence for a connection between the agricultural mechanization and Swing Riots in industrializing England.

The remainder of the paper is structured as follows. First, it develops the theoretical framework. Second, it introduces the historical context. Third, it reports the empirical analyses. Fourth, it interprets the results and then concludes. 


\section{Technology, Inequality, and Violence}

There is now a consensus among economic historians that technological change is one of the fundamental determinants of long-run economic growth and prosperity (see e.g. Mokyr 1992). However, there is also growing awareness that new technologies are not "a rising tide that lifts all boats" but rather a biased process that typically benefits some groups more than it does others, often producing periods of rising inequality. This section of the paper develops a framework for thinking about the likely political consequences of technology-driven inequality, and the conditions under which it generates violence.

One useful framework for thinking about the distributional consequences of technological change is the concept of biased technological change. A new technology is said to be biased when it increases the productivity of some factors of productions (such as land, capital, skilled labor, etc.) more than it does others. When biased technological change favors some factors of

production over others, the wealth that is generated by technological change is distributed unequally across groups in society as a functions of their factor endowments. As a result, quite often technological revolutions often correspond to periods of rapidly rising economic inequality. For a recent example, consider the development of computers and related forms of automation, which have been characterized as a form of skill-biased technological change because they have increased the demand for skilled over unskilled labor, contributing to rising earnings inequality in industrialized countries (Autor, Katz, and Krueger 1998). 
What are the political consequences of technology-driven episodes of rising inequality? Perhaps the original theorist of the political consequences of technological change was Karl Marx, who in the midst of the industrial revolution predicted that the inequality, social dislocation, and class conflict engendered by technological change would result in a working-class political revolution, as workers organized first through trade unions and then through political parties. In The Communist Manifesto (1848) he wrote: "The increasing improvement of machinery, ever more rapidly developing, makes [workers'] livelihood more and more precarious; the collisions between individual workmen and individual bourgeois take more and more the character of collisions between two classes."

Similar arguments can be found in contemporary models in political economy. For instance, Boix (2015) develops a model where the losers of technological change may plunder the beneficiaries if the latter are unable to organize protection. The model of Meltzer and Richard (1981) predicts that voter support for redistribution increases with the level of inequality in society. Similarly, adapting models of the domestic political response to globalization, which increases aggregate wealth but also produces relative winners and losers in a manner analogous to technological change, suggest that governments ought to compensate the relative economic losers as part of an social compact designed to maintain continuing voter support (see e.g. Katzenstein 1985; Rodrik 1998; Walter 2010).

However, despite rising inequality the relative losers of technological change may lack the political power needed to pursue redistribution or compensation through the formal political system. For instance, the relative losers of technological change may not be numerous enough to 
create electoral incentives for political parties to cater to them with promises of redistribution (Przeworski and Sprague 1986). For instance, within the setup of the Meltzer-Richard model, it is possible for biased technological change to increase the dispersion of incomes in society, without necessarily changing the pivotal median voter's incentives to support redistribution. Just as importantly, many governments and party systems may be dominated or captured by an oligarchic elite that is not responsive in any case to voter demands for redistribution or compensation (Wood 2000), especially when these demands emanate from traditionally powerless or subordinate groups that lack the resources needed to engage in large-scale collective action or face social and political repression.

In these contexts, the losers of technological may have to turn to violence to make their demands heard. Well known examples of violent reactions to technological change include the Luddites, a loosely organized movement of skilled English hand weavers who between 1811 and 1816, at the height of the industrial revolution, resorted to smashing the newly invented stocking frames, which rendered their skills obsolete by automating the knitting of textiles (Sale 1996). Similar examples can be found in the case of agricultural technological change, such as the Swing Riots, involving English agricultural workers who engaged in the destruction of threshing machines during the 1830s (Voth and Caprettini 2019), or the Malaysian peasants who resorted to covert sabotage of combine-harvesters during the green revolution of the 1970s (Scott 2008), or the farmers who engaged in rice-burning in response to the green revolution in Ghana (Goody 1980), or the farm workers who engaged in machine-breaking in response to agricultural mechanization in the American Midwest (Argersinger and Argersinger 1984). 
Why do the relative losers of technological engage in such violence? This paper argues that, far from representing senseless or reactionary violence, the violent reaction to biased technological change often represents a form of contentious politics designed to serve at least two strategic purposes. One goal violence may serve is to signal social protest against rising inequality in contravention of customary norms or morals. As EP Thompson and James Scott have argued, technological and economic change that results in concentration of wealth or prices or wages that are perceived to be unfair can prompt violent reactions, ranging from food riots to machinebreaking, designed to express political protest of violations of established norms characterizing a “moral economy” (Thompson 1971; Scott 2008).

Another goal of violence is informal, small-scale redistribution of the surplus generated by technological change. Economic crimes of course in some sense represent a form of small-scale, bilateral redistribution by force. The threat of violence may also compel the relative winners of biased technological to share the gains of biased technological change more fairly with the relative losers through a process of "collective bargaining by riot" (Hobsbawm 1952). The risk of unrest and violence may also encourage firms and employers to slow down the pace of technological change to a rate that is manageable or gives the relative losers time to adapt. For instance, Mokyr (1992a) argues that "Luddite tactics such as arson, and other forms of personal violence have been a highly effective means to combat innovation."

In practice, upsurges of crime that accompany periods of rapid economic and technological change and rising inequality often incorporate both of these aims, selectively deploying forms of violence which both explicitly incorporate elements of social protest against inequality and 
achieve concrete economic goals of subsistence or small-scale redistribution. For example, certain types of economic crime, such as poaching and banditry, also often explicitly incorporate elements of social protest, such as incorporating a code of ethics (e.g. the social bandit that targets only the rich and powerful but not the weak) or targeting visible symbols of inequality (such as targeting royal grounds for poaching) (Hobsbawm 1971; Thompson 2015). That these forms of crime represent not just opportunistic plundering but also express social protest against the prevailing social and political order and the rich and the powerful is reflected in the often extreme repression and disproportionately severe criminal penalties that governments adopt in response (for example, making banditry, machine-breaking or poaching an offence punishable by death) (Ray 1976).

However, I argue, violent reactions to technological change typically represent not the incipient stages of large-scale collective action at the ballot box but "weapons of the weak" because they are typically adopted by groups that lack the political power to advance their aims through overt conflict in the formal political system. In the terminology of Scott (2008), weapons of the weak are informal tactics of class struggle adopted by powerless groups designed to avoid open conflict (Scott 2008). Powerful groups do not need to resort to these tactics, since they are a second-best substitute for organized action through the political system. For example, powerful vested interests that are the losers of technological change are more likely to seek recourse through the political system, for example through lobbying to block technological change or by forcibly redistributing the gains of technological change through legislation (Acemoglu and Robinson 2006; Krusell and Rios-Rull 1996). 
By contrast, though a second-best alternative to redistribution through the political system, in many cases weapons of the weak represent the only practically feasible strategy for powerless groups that are the relative losers of technological change to at least partially express their discontent and achieve some small-scale redistribution through violence. That this violence rarely erupts into organized insurgency, taking instead the form of anonymous, covert, and decentralized crime and violence, such as sabotage, machine-breaking, arson, threatening letters, poaching, banditry, and property damage, that minimizes the risk of identification and out-in-theopen conflict is also illustrative of the point that these tactics are typically adopted from a position of comparative weakness as opposed to strength. If correct, the argument can help to make sense of why we observe so little redistribution of the surplus generated by technological revolutions as well as the upsurge of crime, violence, and contentious politics that often accompanies these periods. The following section applies the argument to the context of a major twentieth-century technological revolution in agriculture, the green revolution in India, and the upsurge of rural crime that accompanied it.

\section{The Green Revolution}

The "green revolution" refers to a period of global agricultural transformation due to the spread of high-yielding variety (HYV) crops. HYV crops were highly productive cultivars first developed by Norman Borlaug and scientists working for the Rockefeller foundation in northern Mexico during the 1950s. Under ideal conditions, the new HYV crops could deliver yields more than double that of traditional varieties. HYV crops swept across the developing world between the 1960s and 1980s, revolutionizing agriculture and ending food shortages. 
HYV seeds were first introduced on a large-scale basis to India from 1966-67 onwards, and distributed initially via a trial programs known as the Intensive Agricultural Districts Program (IADP). The early phase of the green revolution in India was based on the dissemination of the varieties of wheat developed in Mexico and which grew very successfully in the northwestern regions of the country like Punjab. By the mid-1970s, nearly a third of all agricultural land was planted with HYV crops and India went from perennial food shortages to food surpluses. By the 1980s, thanks to the development of HYV cultivars tailored to local conditions by agronomists based at a variety of Indian agricultural research centers, the green revolution also spread to India's rice-growing regions in the east and the south and to arid regions growing millet and pulses in the west. By the end of the 1980s, nearly two thirds of all agricultural land in India was planted with HYV crops (Evenson, Pray, and Rosegrant 1998).

As the green revolution spread, it had the same distributional consequences that commonly accompany periods of biased technological change, including the production of unprecedented wealth as well as inequality. Social scientists studying the early stages of the green revolution in India and other countries noted that the technology overwhelmingly benefited large-scale farmers (Griffin 1979; Frankel 1975). By contrast, especially in the early stages, HYV crops did not benefit smallholders to the same extent. This was because the cultivation of HYV crops was extremely capital intensive, requiring large fixed-cost investments in irrigation and machinery as well as intensive application of fertilizer as well as pesticides to achieve their maximum attainable yields. The resulting economies of scale meant that adoption of the new HYV crops was concentrated among large-scale, entrepreneurial farmers. 
Arguably, the green revolution did improve the incomes of agricultural laborers, especially because the spread of HYV crops, with their shorter duration, and irrigation freed farmers from the traditional limits of a single monsoon-dependent harvest season and led to spread of multiple cropping, resulting in greater labor demand. However, this was partially offset by several countervailing effects, including the spread of agricultural mechanization, especially tractors. While rising demand for labor increased wages, these gains were partially erased by inflation, as well as intensified efforts at labor repression by agricultural employers. As agricultural output improved, so did the quantity or share of harvest that was allocated for transport, storage, and sale on the market as opposed to local consumption. But so too fell the customary share of the harvest allocated by landowners to tenants and laborers (Mencher 1974).

In sum, it could be said for rural India during the green revolution, as Marx had written of the industrial revolution in the Communist Manifesto, that between the 1960s and 1980s "all that is solid melts into air". A patchwork quilt of thousands of localized landraces was replaced with a few HYV cultivars with industrial acronyms like ADT27 and IR8. Traditional planting cycles, attuned to the annual monsoon rainfall, were replaced by double and triple-cropping based upon the exploitation of groundwater on an unprecedented scale (Shiva 2016). Traditional labor relations and customary divisions of the crop were replaced by new forms of mechanization and less generous divisions of the surplus. While the green revolution brought bumper crops and new prosperity to rural India, so too did it bring unprecedented inequality, as some benefited more from technological change than did others. 


\section{Impact on Inequality}

The distributional consequences of HYV crops were complex. To study the bias of the new crop technology empirically, this paper turns to the Additional Rural Incomes Survey (ARIS), a national probability sample survey of rural households carried out by the Indian National Council of Applied Economic Research (NCAER) between 1969 and 1971 during the critical early stages of the green revolution. The ARIS survey provides a valuable source of information to study the distributional consequences of the new crop technology. First, it collected detailed information on the adoption of the new crop technology, details on income and landholdings, as well as information about cultivating practices - providing an opportunity to study bias in the distribution of HYV crop adoption as a function of factor endowments, especially ownership of land. Because the ARIS survey was carried out in multiple waves, the household survey data from 1971 (the most detailed of the three waves) can be linked to a baseline survey of the same households in 1969, providing an opportunity study whether the differential adoption of HYV crops across households over time contributed to rural inequality.

Figure 1 provides reports descriptive statistics on average rates of HYV crop adoption across cultivating households divided into quartiles of landholdings, computed after taking into account the survey weights. The data suggests that rates of adoption of the new crop technology were increasing in land endowments, with an estimated 17.73 percent of households in the bottom quartile of the distribution of the amount of land cultivated adopting HYV crops and 39.77 percent of households in the top quartile adopting HYV crops in 1971. This bears out qualitative fieldwork suggesting that access to the new crop technology was heavily concentrated among 
farmers with the larger landholdings required to profitably cultivate the input-intensive new crop technology as opposed to small-scale farmers.

\section{FIGURE 1 ABOUT HERE}

Table 1 examines the impact of differential rates of HYV crop adoption on rural inequality using panel data. Approximately 90 percent or 4118 or 4527 households in the 1971 survey could be connected to households surveyed initially during the 1969 wave, providing an opportunity compare changes in the income of households adopting HYV crops versus those experiencing no change in their technology adoption status between 1969 and 1971. To account for time-invariant household-specific omitted variables I estimate regressions that control for household fixed effects as well as village-year fixed effects, ensuring that we estimate the impact of over-time changes in HYV crop adoption across households located within the same village. Table 1 reports the regression estimates. Columns (1) and (2) examine impacts across the full sample of all households in the dataset, indicating that households adopting HYV crops experienced a 7.3 percent increase in per capita household income and a 3.9 percent improvement in per capita household consumption relative to households not adopting HYV crops between 1969 and 1971. Columns (3) and (4) conduct the same analysis, restricting the sample to households who in the baseline survey reported that the household head derived their income primarily from agriculture; a very similar pattern of results is found. Columns (5) and (6) restrict the sample to households who in the baseline survey cultivated at least some land; again, we find a similar emergence of an increasing gap between the incomes of households adopting HYV crops versus those cultivating traditional varieties. 


\section{TABLE 1 ABOUT HERE}

Early field researchers feared that the growing rural inequality due to the green revolution could fuel support for a communist revolution in the countryside. In 1969, the political scientist Francine Frankel (1975) toured several of the Intensive Agricultural Districts Program (IADP) districts selected for early propagation of HYV crops in India and came to a grim conclusion: by widening economic inequality in India, the green revolution was fomenting social and political unrest among the relative losers of technological change, in this case the landless poor and smallscale and tenant farmers. If not addressed, rising inequality could result in mass support for communist and left-wing parties and other "extremist" movements, she concluded.

These fears did not seem farfetched in the context of the Cold War and the spread of communism in the countryside in nearby southeast Asia. The domestic political context of the early postindependence decades in India also mattered. The Congress party dominated electorally in virtually every state in India, but the best organized threat to its position of dominance came from the left, from socialist and communist opposition parties which, in some states, were making significant inroads. Warned a 1969 report published by India's Home Ministry on The Causes and Nature of Current Agrarian Tensions: "The tensions in the rural areas, resulting from the widening gap between the relatively few affluent farmers and the large body of small landholders and landless agricultural laborers, may increase in the coming months and years.... (quoted in Siegel 2018 p. 214)" 
In retrospect, we know that a communist revolution never materialized in the Indian countryside. In fact, the primary long-term political consequences of the green revolution were to mobilize the winners of technological change into politics, resulting in the emergence of agrarian opposition movements and parties representing the interests of prospering agricultural producers and cultivating caste groups in the countryside, which played a critical role in the decline of single-party dominance and emergence of multi-party competition in India (see e.g. Dasgupta 2018; Varshney 1998).

It is, however, important to understand why a communist revolution never materialized or this case of the "dog that did not bark". This paper argues that protest against inequality and demands for redistribution took the form not of a left-wing revolution at the ballot box but an epidemic of rural crime, specifically dacoity (rural banditry), because the relative losers of technological change, in this case the rural poor, lacked the political power to pursue their aims through the formal party system. The dominant Congress party's basis of political support in rural India at this time was a "coalition of extremes" comprising rural elites who dominated local party organization as well as patron-client ties to the rural poor, which by design offered little scope for grassroots mobilization or autonomous political action by the rural poor (see e.g. Brass 1965; Bailey 1970; Weiner 1967). Though in the abstract the laborers and tenants may have been receptive to promises of land reform and rural redistribution by left-wing parties, outside of two states (West Bengal and Kerala) as a practical matter communist and socialist parties in India were characterized by a serious urban bias and possessed little organization presence in the countryside that would have facilitated large-scale mobilization of poor voters behind a redistributive agenda (Kohli 1987). 
Due to the prohibitive difficulty of articulating demands for redistribution within the party system, I argue that the reaction to rising rural inequality during the green revolution took instead the form of an upsurge in rural violence, especially in the form of dacoity. As Figure 2 depicts, India experienced an epidemic dacoity, beginning precisely around the time that HYV crops were introduced to India, while the seat share of left-wing parties was, if anything, declining over the same period of time. Panel (a) of Figure 2 depicts the annual number of dacoities reported in annual reports published India's National Crime Records Bureau. Panel (b) of Figure 2 depicts the average district-level state assembly seat share of the major left-wing parties across the 270 districts in India's major states that are in the empirical sample of this study, based on electoral data collected and digitized by Jensenius (2013).

\section{FIGURE 2 ABOUT HERE}

The upsurge of dacoity over this time period is salient because it is a type of crime with traditional elements of social protest against inequality. Legally, dacoity is defined in the Indian Penal Code as an act of armed or violent robbery committed by a gang of five or more people, the maximum sentence for is life imprisonment. In terms of social significance, dacoits in folk tradition have often represented what Hobsbawm famously termed "social bandits" who "were not regarded as simple criminals by public opinion" but as Robin Hood-style outlaws whose activities represented "a form of individual or minority rebellion within peasant societies" against the oppression of landlords and authorities and whose survival depended to some extent on popular legitimacy, especially among the rural poor (Hobsbawm 1971). 
In rural folklore, myth and oral tradition dating to the eighteenth and nineteenth centuries, famous dacoits were often noble outlaws who abided by a code of ethics, bringing violence and retribution against upper-caste elites, exploitative traders, and corrupt landlords and colonial authorities, but not the rural poor (Guha 1999). One can also read the folk tradition through "inversion" of the representation of dacoits in colonial reports. British colonial authorities viewed dacoity as a form of near-mutinous "law and order problem" that had to be stamped out, with repressive laws such as the Thuggee and Dacoity Suppression Acts legislated between 1836 and 1848. In bedtime stories targeted at the rural landed gentry, dacoits were represented as cultists who committed ritual murder, or sometimes as the equally dreaded seemingly obedient servant or laborer turned dacoit by nightfall (Rushby 2003).

In India, the upsurge of dacoity during the 1970s and 1980s was reflected in an explosion of Bollywood films which drew upon these folk traditions with dacoits cast either as heroes or as villains. Real dacoits, such as the "bandit queen" Phoolan Devi or Paan Singh Tomar, an Indian solider and international athlete-turned-dacoit, or Veerappan, the elusive poacher and politiciankidnapper, flourished during this period and acquired celebrity as outlaw heroes fighting back against oppressive rural power structures, often styling themselves as baaghis (rebels) rather than criminals. Equally, the Indian state organized militarized large-scale crackdowns, resembling counter-insurgency operations, against dacoity in rugged regions like the Chambal ravines or Bundelkhand, with often highly theatrical "voluntary surrenders" of dacoits arranged by civil society leaders like Jayprakash Narayan. 
Folk traditions of social protest aside, dacoits were also criminals with practical economic motives; nevertheless, the economic organization of dacoity meant that as a scarcity crime it served as an informal form of small-scale redistribution of wealth not just to professional dacoits, but to ordinary villagers connected through social networks to dacoits or who participated in dacoity temporarily. As a result, dacoity tended to flourish during periods of scarcity such as famines and droughts (Arnold 1979). While some dacoits were lifelong professional criminals, available evidence suggests that dacoit gangs historically relied heavily on recruiting out of work young men into their ranks through kinship networks during periods of economic hardship (Das 2007). Dacoits also relied on diffuse social networks, with ordinary villagers serving as informants about potential targets for robbery as well as providing tacit or explicit support, whether out of fear or loyalty, for their activities by remaining silent or sharing information about potential police activities.

Table 2 provides evidence that the occurrence of dacoity at the district level tended to increase during droughts and negative rainfall shocks, consistent with a logic of small-scale redistribution during periods of economic hardship. District-level data on total annual incidents of dacoity comes from from the National Crime Records Bureau (NCRB) from 1971 onward. This is connected to district-level data on a variety of agricultural statistics, including rainfall, compiled by Sanghi et al. (1998) into a panel dataset that covers 270 districts between 1957 and 1987 across India's major states. In columns (1) and (2), I estimate panel fixed-effects regression which look at the impact of standardized deviations of rainfall from a district's long-term mean on the occurrence of dacoity. As the negative coefficients illustrate, following a better-thanaverage monsoon rainfall in a district, dacoities tended to fall, and, conversely, following a 
worse-than-average monsoon rainfall in a district, dacoities tend to rise. As the coefficients on the leading rainfall variables indicate, rainfall shocks exerted persistent impacts on the occurrence of dacoity that remained even a few years later, potentially due to the permanent recruitment effects of temporary income shocks. Columns (3) and (4) are placebo tests, and reveal that no such pattern is found in the case of non-economic violent crimes (the sum of all murders, culpable homicides, rapes, and kidnappings) which we would not expect to follow a logic of small-scale redistribution during periods of scarcity (Blakeslee and Fishman 2018).

\section{TABLE 2 ABOUT HERE}

The preceding discussion has demonstrated that dacoity, as a form of crime, has traditionally contained elements of social protest against economic inequality as well as served as a form of informal, small-scale redistribution during periods of scarcity. The upsurge of dacoity that took place during the green revolution may well have represented tactics of violence adopted by the relative losers of technological change which both explicitly incorporate elements of social protest against inequality and achieve concrete economic goals of subsistence or redistribution, in a context where demands for redistribution did not find articulation in the party system, where local party organization was dominated by rural elites, and where linkages to the rural poor typically took the form of patron-client ties. The following section conducts systematic empirical analyses of whether the spread of the new crop technology across districts was associated with the rise in dacoity as well as whether this plausibly represented informal tactics of protest and redistribution, as theorized. 


\section{Empirical Analysis}

District-level data on total annual incidents of crime comes from the National Crime Records Bureau (NCRB). The data are collected from police stations and district-level authorities and are aggregated and produced in an official report, Crime in India, that is published annually. Statistics are available for eleven categories of reported crime, including murder, culpable homicide, rape, kidnapping, riot, breach of trust, cheating, counterfeiting, theft, robbery and dacoity. I digitized these district-level crime statistics for the period 1971-1987 (unfortunately, data prior to 1971 is only reported at the aggregated state level), corresponding to the peak years of technological change during the green revolution in India.

The digitized data on district-level crime records is then connected to district-level panel data on the share of agricultural land planted with HYV crops between 1957 and 1987 across India's major states. The data on HYV crop adoption comes from annual Indian agricultural surveys. Indian government officials have regularly collected crop production statistics based on agricultural surveys since independence; these data were compiled by Sanghi et al. (1998) into a panel dataset that measures district-level HYV crop adoption across 270 districts across. To account for splits of districts over time, all data are aggregated to the level of 1961 district boundaries. Figure 3 depicts maps of districts shaded according to average HYV crop adoption as well as average annual occurrence of dacoity.

FIGURE 3 ABOUT HERE 
To estimate the impact of the spread of the new crop technology on rural crime, I estimate panel fixed effects regressions which estimate the impact of within-district variation over-time in the adoption of HYV crops on the annual incidence of different types of crime, while also partialing out time-invariant omitted variables as well as common time trends and shocks. I estimate two types of models: a simple OLS regression with district and year or region-year fixed effects as well as a Poisson regression equation, which is technically better suited to the analysis of outcomes which take the form of count data (e.g. number of incidents of dacoity). In all specifications, I estimate standard errors adjusted for two-clustering both within districts over time and spatially across districts within years.

Table 3 reports the main results. Columns (1) and (2) report the OLS specifications. Column (1) suggests that as the share of a district's agricultural land planted with HYV crops goes from zero to one, the average annual occurrence of dacoities increases by about 18 additional dacoities per year, a large impact relative to the sample average occurrence of 44 dacoities per district-year and which represents about a 0.57 within-district standard deviation increase in the occurrence of this form of crime. Column (2) estimates a similar specification but additionally controls for region-year fixed effects (where the regions are states in the north, south, east, and west, respectively), ensuring that the regression estimates are driven by over-time comparisons pf districts within the same region. A very similar, and in fact slightly larger, coefficient is estimated in this specification.

TABLE 3 ABOUT HERE 
Columns (3) and (4) report the Poisson regression coefficients. To compute the effect of HYV crop adoption on the rate of crime and violence, the substantive quantity of interest, I exponentiate the coefficient on the treatment indicator from the Poisson regressions (which gives the incidence rate ratio), and subtract 1 to compute the estimated percentage change in crime and violence resulting from a district going from no land under HYV crops to all agricultural land planted with HYV crops. The estimates suggest that as the share of a district's agricultural land planted with HYV crops goes from zero to one, the number of dacoities committed in a district increases by approximately 150 percent, an extremely large effect consistent with the spread of the new crop technology playing a critical role in the upsurge of dacoity which occurred during the 1970s and 1980s in India.

Table 4 reports placebo tests, examining the impact of HYV crop adoption (using a panel fixedeffects OLS specification; the Poisson regression estimates are substantively identical) on every other form of crime reported in the NCRB reports. These placebo tests show that there was no connection between HYV crop adoption and increases in any other form of economic or noneconomic crime. In fact, most of the coefficients in this table are negative, consistent with the ordinarily posted relationship between development and conflict. The only specification with a substantially positive (but not statistically significant) coefficient looks at the impact of HYV crop adoption on robbery, the legal definition of which is almost identical to that of dacoity, except that robbery is committed by fewer than five assailants. These results suggest that the epidemic of dacoity in districts where the new crop technology was spreading was driven not just by opportunistic plundering but a selective form of violence representing social protest and small-scale redistribution in a context of rising rural inequality. 


\section{TABLE 4 ABOUT HERE}

What was the impact of HYV crops on the electoral performance of left-wing political parties? I next perform a similar analysis to examine the impact of HYV crops on the electoral performance in state assembly elections of major left-wing parties. Electoral data on over 20,000 election races between 1957 and 1987 were geo-coded to the districts in the sample between 1957 and 1987, the key decades of the green revolution, on the basis of archival records from the Election Commission of India. I then examine statistically whether changes in HYV crop adoption impacted the district-level performance of left-wing political parties at the ballot box, while controlling for district and year or region-year fixed effects. Table 5 reports the regression results. These empirical analyses reveal that increases in HYV crop adoption did not strengthen the electoral performance of left-wing parties, with coefficients that are small, negative, precisely estimated, and statistically indistinguishable from zero. These results suggest that the epidemic of banditry in districts where the new crop technology was spreading was not a precursor to but a substitute for large-scale collective action at the ballot box, which would have been prohibitively difficult for poor and rural voters in a hierarchical rural context where local party organization was dominated by rural elites, and where linkages to the rural poor typically took the form of patron-client ties.

TABLE 5 ABOUT HERE 


\section{Conclusion}

This paper has examined the political consequences of biased technological change during one of the major technological revolutions in agriculture of the twentieth century: the green revolution in India, which generated wealth as well as growing rural inequality. Contrary to the expectations of many early observers, growing inequality between landowners and the rural poor due to the spread of HYV crops did not produce a communist revolution in the countryside. Instead, it produced an epidemic of rural violence, specifically in the form dacoity (rural banditry), a form of crime with elements of social protest against inequality and which also served as an informal form of small-scale redistribution.

Though canonical theories in political economy suggest that inequality automatically leads to redistribution, I have argued that the epidemic of banditry that occurred during the green revolution is illustrative of what happens when the relative losers of technological change lack the political power needed to pursue redistribution or compensation through the political system: they sometimes turn to or informal tactics of protest and redistribution instead, including crime and violence. Far from senseless, this violence is better seen as a form of contentious politics that takes place when large-scale collective action through the formal political system is infeasible or unlikely to be successful, forcing the relative losers of technological change to turn to "weapons of the weak" instead.

The findings shed new light on the political economy of technological change, including the puzzle of why technological revolutions are characterized by so little redistribution of surplus 
and so much violence. In the context of rural India, available repertoires of contention meant that this violence took the form of dacoity. A promising topic for future research would be to explore other contentious tactics that have been deployed in other historical contexts, including but not limited to crime and violence, as well as the precise conditions under which the relative losers of technological change resort to these tactics as opposed to attempts at large-scale collective action through the formal political system. 


\section{Works Cited}

Acemoglu, Daron, and James A. Robinson. 2006. "Economic Backwardness in Political Perspective." American Political Science Review 100 (1): 115-31.

Allen, Robert C. 2009. "Engels' Pause: Technical Change, Capital Accumulation, and Inequality in the British Industrial Revolution." Explorations in Economic History 46 (4): 418-35.

Argersinger, Peter H., and Jo Ann E. Argersinger. 1984. "The Machine Breakers: Farmworkers and Social Change in the Rural Midwest of the 1870s." Agricultural History, 393-410.

Arnold, David. 1979. "Dacoity and Rural Crime in Madras, 1860-1940." The Journal of Peasant Studies 6 (2): 140-67.

Autor, David H., Lawrence F. Katz, and Alan B. Krueger. 1998. "Computing Inequality: Have Computers Changed the Labor Market?" The Quarterly Journal of Economics 113 (4): 1169-1213.

Autor, David H., Frank Levy, and Richard J. Murnane. 2003. "The Skill Content of Recent Technological Change: An Empirical Exploration.” The Quarterly Journal of Economics 118 (4): 1279-1333.

Bailey, Frederick George. 1970. Politics and Social Change: Orissa in 1959. Univ of California Press.

Blakeslee, David S., and Ram Fishman. 2018. "Weather Shocks, Agriculture, and Crime Evidence from India." Journal of Human Resources 53 (3): 750-82.

Boix, Carles. 2015. Political Order and Inequality. Cambridge University Press.

Brass, Paul R. 1965. Factional Politics in an Indian State: The Congress Party in Uttar Pradesh. Univ of California Press.

Das, Suranjan. 2007. "Behind the Blackened Faces: The 19th Century Bengali Dacoits." Economic and Political Weekly, 3573-79.

Dasgupta, Aditya. 2018. "Technological Change and Political Turnover: The Democratizing Effects of the Green Revolution in India." American Political Science Review 112 (4): 918-38.

Evenson, Robert Eugene, Carl Pray, and Mark W. Rosegrant. 1998. Agricultural Research and Productivity Growth in India. Vol. 109. Intl Food Policy Res Inst.

Frankel, Francine R. 1975. India's Green Revolution. Princeton University Press.

Goody, Jack. 1980. "Rice-burning and the Green Revolution in Northern Ghana." The Journal of Development Studies 16 (2): 136-55.

Griffin, Keith. 1979. The Political Economy of Agrarian Change: An Essay on the Green Revolution. Springer.

Guha, Ranajit. 1999. Elementary Aspects of Peasant Insurgency in Colonial India. Duke University Press.

Hobsbawm, Eric J. 1952. “The Machine Breakers.” Past \& Present, no. 1: 57-70.

- 1971. Primitive Rebels: Studies in Archaic Forms of Social Movement in the 19th and 20th Centuries. Manchester University Press.

Jensenius, Francesca Refsum. 2013. "Power, Performance and Bias: Evaluating the Electoral Quotas for Scheduled Castes in India." UC Berkeley.

Katzenstein, Peter J. 1985. Small States in World Markets: Industrial Policy in Europe. Cornell University Press.

Kohli, Atul. 1987. The State and Poverty in India: The Politics of Reform. Cambridge Univ. Press. 
Krusell, Per, and Jose-Victor Rios-Rull. 1996. "Vested Interests in a Positive Theory of Stagnation and Growth." The Review of Economic Studies 63 (2): 301-29.

Meltzer, Allan H., and Scott F. Richard. 1981. "A Rational Theory of the Size of Government." Journal of Political Economy 89 (5): 914-27.

Mencher, Joan P. 1974. "Conflicts and Contradictions in the 'Green Revolution': The Case of Tamil Nadu." Economic and Political Weekly, 309-23.

Mokyr, Joel. 1992a. "Technological Inertia in Economic History." The Journal of Economic History 52 (2): 325-38.

- 1992b. The Lever of Riches: Technological Creativity and Economic Progress. Oxford University Press.

Przeworski, Adam, and John Sprague. 1986. Paper Stones: A History of Electoral Socialism. University of Chicago Press.

Ray, Gerda. 1976. Albion's Fatal Tree: Crime and Society in Eighteenth Century England. JSTOR.

Rodrik, Dani. 1998. "Why Do More Open Economies Have Bigger Governments?” Journal of Political Economy 106 (5): 997-1032.

Rushby, Kevin. 2003. Children of Kali: Through India in Search of Bandits, the Thug Cult, and the British Raj. Bloomsbury Publishing USA.

Sale, Kirkpatrick. 1996. Rebels against the Future: The Luddites and Their War on the Industrial Revolution: Lessons for the Computer Age. Basic Books.

Scott, James C. 2008. Weapons of the Weak: Everyday Forms of Peasant Resistance. Yale University Press.

Shiva, Vandana. 2016. The Violence of the Green Revolution: Third World Agriculture, Ecology, and Politics. University Press of Kentucky.

Siegel, Benjamin Robert. 2018. Hungry Nation: Food, Famine, and the Making of Modern India. Cambridge University Press.

Thompson, Edward P. 1971. "The Moral Economy of the English Crowd in the Eighteenth Century." Past \& Present, no. 50: 76-136.

- 2015. Whigs and Hunters. Breviary Stuff Pub.

Varshney, Ashutosh. 1998. Democracy, Development, and the Countryside: Urban-Rural Struggles in India. Cambridge University Press.

Voth, Hans-Joachim, and Bruno Caprettini. 2019. "Rage Against the Machines: Labor-Saving Technology and Unrest in Industrializing England." American Economic Review: Insights Forthcoming.

Walter, Stefanie. 2010. "Globalization and the Welfare State: Testing the Microfoundations of the Compensation Hypothesis.” International Studies Quarterly 54 (2): 403-26.

Weiner, Myron. 1967. Party Building in a New Nation: The Indian National Congress. [Chicago]: University of Chicago Press.

Wood, Elisabeth Jean. 2000. Forging Democracy from below: Insurgent Transitions in South Africa and El Salvador. Cambridge University Press. 


\section{Figures and Tables}

FIGURE I. HYV Crop Adoption Rates by Land Endowment

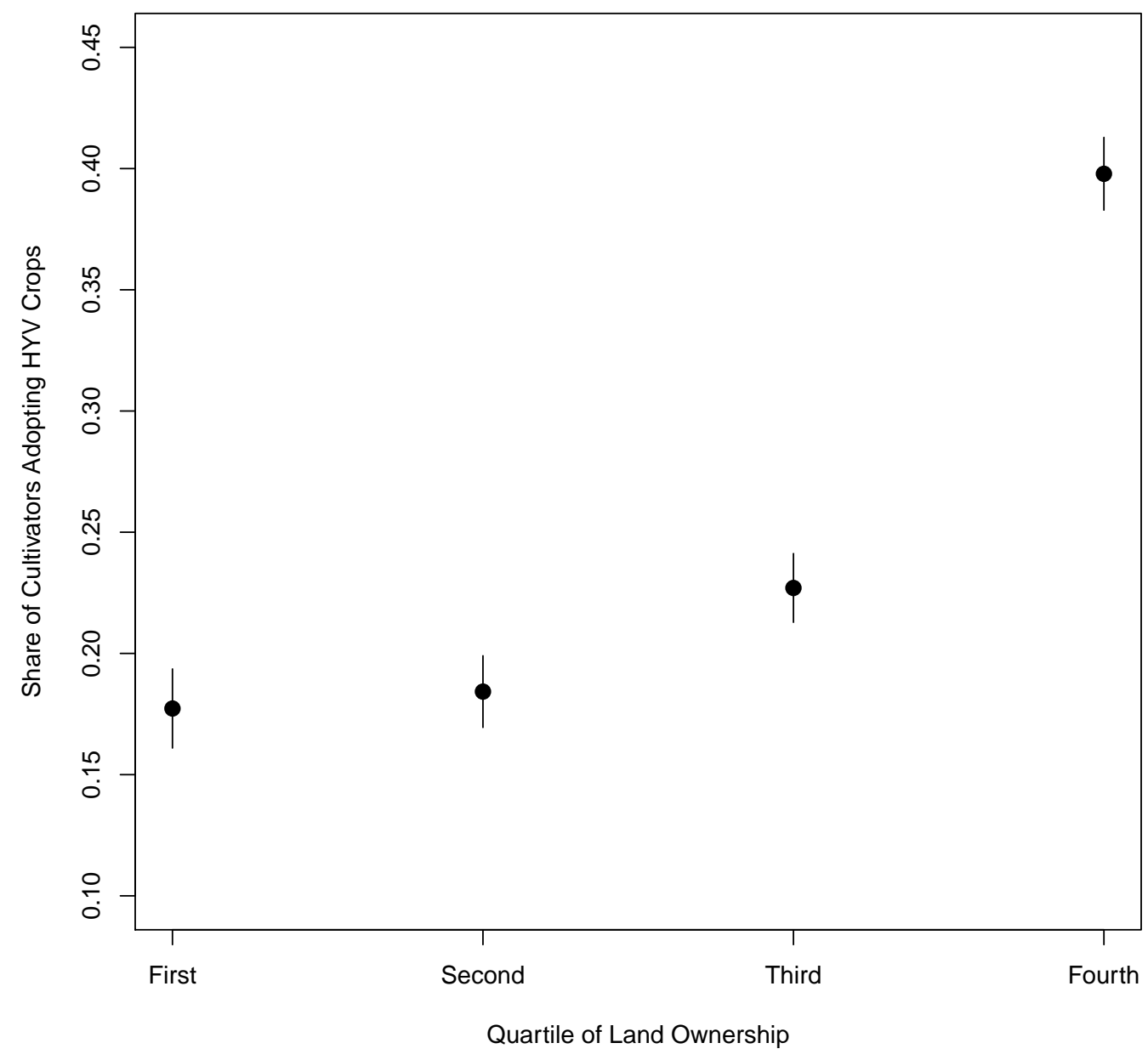

Notes: Figure represents estimated HYV crop adoption rates by quartile of amount of land cultivated among cultivating households in 1971. Vertical bars represent average plus or minus one standard error. Data from ARIS survey. 


\section{TABLE I. Impact of HYV Crop Adoption on Intra-village Inequality}

\begin{tabular}{|c|c|c|c|c|c|c|}
\hline & \multicolumn{6}{|c|}{ Dependent variable: } \\
\hline & $\log ($ Income $)$ & $\log ($ Consumption $)$ & $\log$ (Income) & $\log ($ Consumption $)$ & $\log$ (Income) & $\log ($ Consumption $)$ \\
\hline & $(1)$ & (2) & (3) & (4) & (5) & (6) \\
\hline HYV & $\begin{array}{c}0.073^{* *} \\
(0.029)\end{array}$ & $\begin{array}{l}0.039^{*} \\
(0.022)\end{array}$ & $\begin{array}{c}0.071^{* *} \\
(0.031)\end{array}$ & $\begin{array}{c}0.035 \\
(0.023)\end{array}$ & $\begin{array}{c}0.066^{* *} \\
(0.031)\end{array}$ & $\begin{array}{c}0.024 \\
(0.024)\end{array}$ \\
\hline Observations & 8,220 & 8,234 & 6,203 & 6,206 & 5,884 & 5,896 \\
\hline Village-Year FE & Yes & Yes & Yes & Yes & Yes & Yes \\
\hline Household FE & Yes & Yes & Yes & Yes & Yes & Yes \\
\hline Sample & Full & Full & Agricultural & Agricultural & Cultivators & Cultivators \\
\hline Adjusted $\mathrm{R}^{2}$ & 0.681 & 0.661 & 0.711 & 0.688 & 0.702 & 0.670 \\
\hline
\end{tabular}

Notes: Unit of observation is household-survey wave (in 1969 and 1971). Outcome is the natural log of reported household per capita income and consumption. All specifications control for household and village-year fixed effects. Standard errors are adjusted for clustering within villages. 


\section{FIGURE II. Rural banditry and Left-wing party performance}

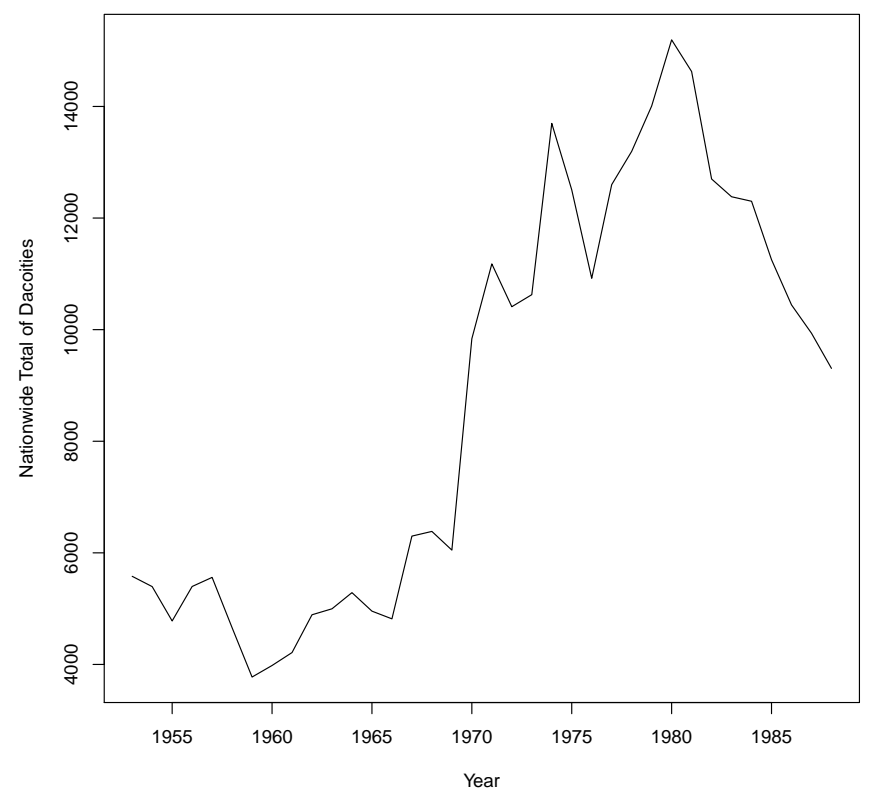

(a) Dacoities over Time

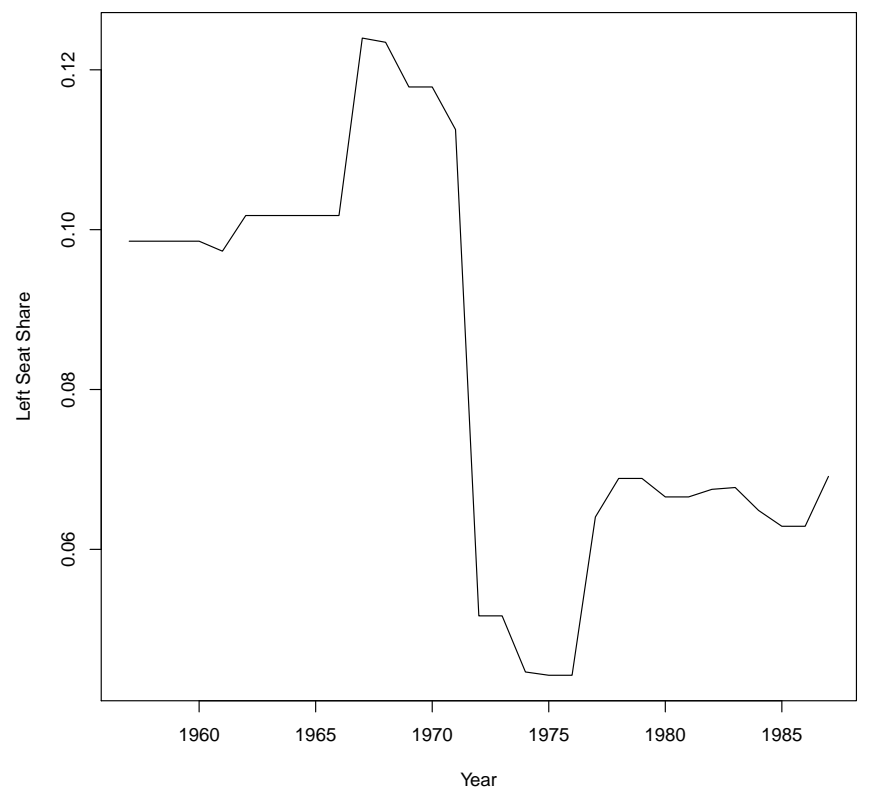

(b) Left-wing party seat share over time

Notes: Plot in panel (a) depicts total numbers of dacoities committed annually according National Crime Records Bureau Database. Plot in panel (b) depicts average district-level state assembly seat share of major left-wing parties (Communist party of India-Marxist, Communist Party of India, Praja Socialist Party, Samyukta Socialist Party, Peasants and Workers Party, Forward33oc) across 270 districts in study. 
TABLE II. Dacoity Responds to Economic Conditions (Rainfall Shocks)

\begin{tabular}{|c|c|c|c|c|}
\hline & \multicolumn{4}{|c|}{ Dependent variable: } \\
\hline & \multicolumn{2}{|c|}{ Dacoity } & \multicolumn{2}{|c|}{ Violent Crimes } \\
\hline & $(1)$ & $(2)$ & $(3)$ & $(4)$ \\
\hline standardized rain $_{t}$ & $\begin{array}{c}-2.579^{* *} \\
(1.294)\end{array}$ & $\begin{array}{l}-1.612 \\
(1.390)\end{array}$ & $\begin{array}{c}1.543 \\
(2.493)\end{array}$ & $\begin{array}{c}0.851 \\
(2.811)\end{array}$ \\
\hline standardized rain $_{t-1}$ & $\begin{array}{l}-1.609 \\
(1.541)\end{array}$ & $\begin{array}{l}-1.792 \\
(1.551)\end{array}$ & $\begin{array}{l}-1.994 \\
(2.064)\end{array}$ & $\begin{array}{l}-3.036 \\
(2.294)\end{array}$ \\
\hline standardized rain $_{t-2}$ & $\begin{array}{c}-3.459^{* * *} \\
(1.224)\end{array}$ & $\begin{array}{c}-2.406^{*} \\
(1.449)\end{array}$ & $\begin{array}{c}0.427 \\
(2.201)\end{array}$ & $\begin{array}{c}1.163 \\
(2.435)\end{array}$ \\
\hline standardized rain $_{t-3}$ & $\begin{array}{c}-2.098^{*} \\
(1.109)\end{array}$ & $\begin{array}{c}-2.458^{* *} \\
(1.197)\end{array}$ & $\begin{array}{l}-1.410 \\
(2.095)\end{array}$ & $\begin{array}{l}-2.398 \\
(2.161)\end{array}$ \\
\hline District FE & Yes & Yes & Yes & Yes \\
\hline Time FE & Year & Region-year & Year & Region-year \\
\hline Observations & 4,320 & 4,320 & 4,320 & 4,320 \\
\hline Adjusted $\mathrm{R}^{2}$ & 0.768 & 0.776 & 0.624 & 0.626 \\
\hline
\end{tabular}

Notes: Unit of analysis is district-year, observed across 270 districts between 1972 and 1987. Standardized rainfall is the standardized rainfall in a district in a given year. Standard errors adjusted for two-way clustering with districts and within region-years. Analysis estimated by OLS. 


\section{FIGURE III. Maps of Data by District}

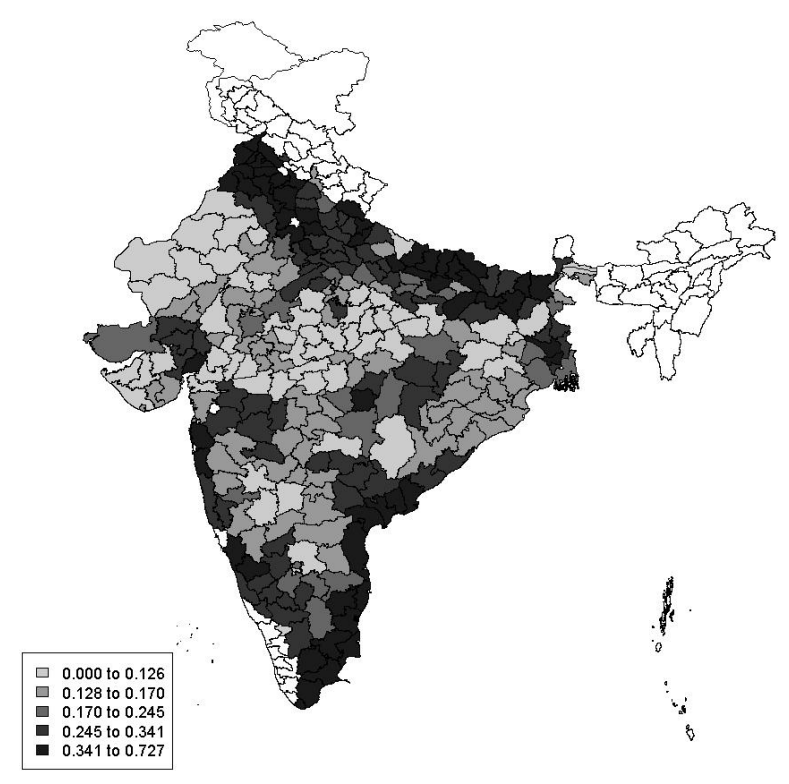

(a) Mean HYV Crop Adoption

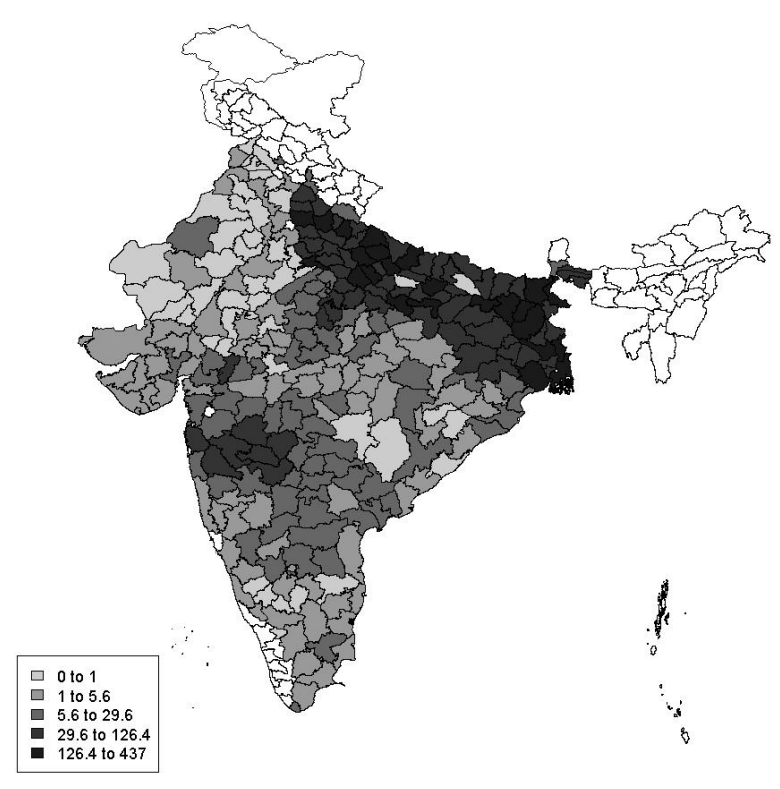

(b) Mean Dacoities

Notes: Plot in panel (a) depicts average share of agricultural land planted with HYV crops between 1967 and 1987. Plot in panel (b) depicts average annual district-level occurrences of dacoity (rural banditry) between 1971 and 1987 according to digitized historical reports of the National Crime Records Bureau. All data are aggregated to the level of 1961 district boundaries. 35 
TABLE III. Impact of HYV Crop Adoption on Dacoity

\begin{tabular}{|c|c|c|c|c|}
\hline & \multicolumn{4}{|c|}{ Dependent variable: } \\
\hline & \multicolumn{2}{|c|}{ OLS } & \multicolumn{2}{|c|}{ Poisson } \\
\hline & $(1)$ & $(2)$ & (3) & $(4)$ \\
\hline HYV Crop Adoption & $\begin{array}{c}17.881^{* *} \\
(8.498)\end{array}$ & $\begin{array}{c}21.387^{* *} \\
(9.943)\end{array}$ & $\begin{array}{c}0.929 * * * \\
(0.284)\end{array}$ & $\begin{array}{c}0.893^{* * *} \\
(0.300)\end{array}$ \\
\hline Implied impact & $+0.57 \mathrm{SD}$ & $+0.70 \mathrm{SD}$ & $+153 \%$ & $+144 \%$ \\
\hline District FE & Yes & Yes & Yes & Yes \\
\hline Time FE & Year & Region-year & Year & Region-year \\
\hline Observations & 4,320 & 4,320 & 4,320 & 4,320 \\
\hline Adjusted $\mathrm{R}^{2}$ & 0.768 & 0.776 & 0.624 & 0.626 \\
\hline
\end{tabular}

Notes: Unit of analysis is district-year, observed across 270 districts between 1972 and 1987. HYV is share of agricultural land planted with HYV crops. Standard errors adjusted for two-way clustering with districts and within region-years. Analysis estimated by OLS or Possion regression. 


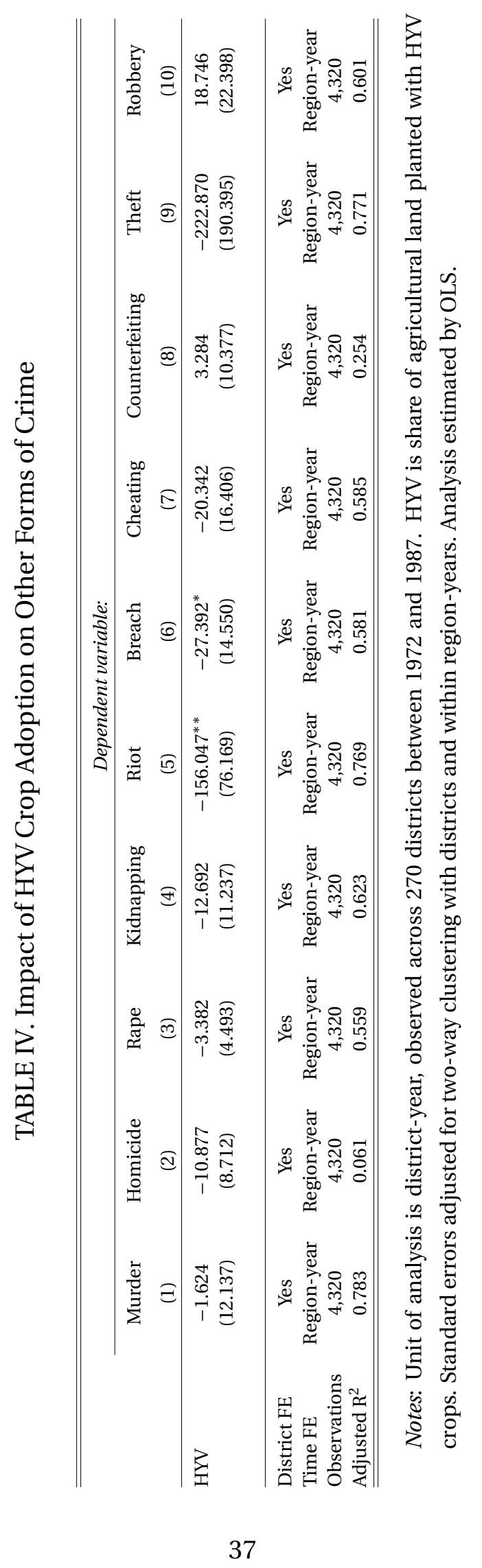




\section{TABLE V. Impact of HYV Crops on Left-wing Parties}

\begin{tabular}{lcc}
\hline \hline & \multicolumn{2}{c}{ Dependent variable: } \\
\cline { 2 - 3 } & \multicolumn{2}{c}{ Seat Share } \\
& $(1)$ & $(2)$ \\
\hline HYV & -0.036 & -0.031 \\
& $(0.040)$ & $(0.037)$ \\
\hline District FE & Yes & Yes \\
Time FE & Year & Region-year \\
Observations & 8,290 & 8,290 \\
Adjusted $\mathrm{R}^{2}$ & 0.318 & 0.368 \\
\hline \hline
\end{tabular}

Notes: Unit of analysis is district-year, observed across 270 districts between 1957 and 1987. Outcome is district-level seat share of left-wing parties in state assembly elections. HYV is share of agricultural land planted with HYV crops. Standard errors adjusted for two-way clustering with districts and within years. Analysis estimated by OLS. 